\title{
PHYTOREMEDIATION AS TOOL FOR PREVENTION OF CONTAMINANT FLOW TO HYDROLOGICAL SYSTEMS
}

\author{
Kristine Valujeva ${ }^{1}$, Juris Burlakovs ${ }^{2}$, Inga Grinfelde ${ }^{1}$, Jovita Pilecka ${ }^{1}$, Yahya Jani ${ }^{2}$, William Hogland ${ }^{2}$ \\ ${ }^{1}$ Latvia University of Life Science and Technologies, Latvia \\ ${ }^{2}$ Linnaeus University, Sweden \\ Kristine.Valujeva@gmail.com
}

\begin{abstract}
Management of remediation projects in contaminated sites has become an increasingly global challenge and nowadays takes intensive international environmentally sound cooperation intended to relieve negative consequences of landscape pollution. This paper aims to deal with the phytoremediation approach for protection of environment and preventing the streaming of contaminant flows to hydrological systems. Phytoremediation is a cost-effective environmentally friendly clean-up technology, which uses plants and microorganisms in rhizosphere for soil and groundwater treatment. Phytoremediation is enhancing degradation of organic pollutants and improving stabilization of inorganic contaminants where plants can be used to treat soil and water polluted with hydrocarbons, chlorinated substances, pesticides, metals, explosives, radionuclides as well as to reduce the excess of nutrients. Selection of species for this type of treatment processes is based on evapotranspiration potential and ability to bioaccumulate contaminants. The project entitled "Phytoremediation Park for treatment and recreation at glassworks contaminated sites" (PHYTECO) aimed at cross-sector international partnership. The challenge of project was to develop remediation strategy where negative consequences from centuries long anthropogenic influence are turned to be something positive - development of the recreation park from the glass dump. Here designers, scientists, local volunteers, international students would join ideas and common work for the boost of innovation and sustainable thinking. New "Knowledge in Inter Baltic Partnership Exchange for Future Regional Circular Economy Cooperation" (PECEC) project is sequential continuation.
\end{abstract}

Key words: contaminated sites, heavy metals, oil products, phytostabilization, remediation.

\section{Introduction}

Remediation is clean-up, mitigation, correction, abatement, minimizing, elimination, control and containment or prevention of a release of contamination thereby protecting human health and environment (9VAC20-160-10, Definitions, 1997). Clean-up technologies improve environmental quality and remove historically and actually contaminated sites to minimize loss of land as a resource and treat groundwater problem by preventing contaminant flows to hydrologic systems (Directive 2008/1/EC, 2008). Low energy and resource use, low waste production, minimized footprint and innovations are recommended characteristics for feasible remediation technologies (Schrenk et al., 2007). The decision on choice of remediation technologies should take in account:

a) Short-term and/or long-term effectiveness;

b) Effectiveness of contaminant reduction at the site;

c) Reduction of contaminant toxicity;

d) Cost effectiveness of remediation.

Remediation technologies can be divided as in situ and ex situ technologies; according to the scope of application - vadose and saturated zone technologies; taking into account the processes used as biological, physical separation, chemical, physical-chemical, thermal, and containment techniques (Prokop, Schamann, \& Edelgaard, 2000).

Phytoremediation itself is a cost-effective and using plants and microorganisms associated in root system (rhizosphere) as soil and groundwater treatment agents. Plants and microbial communities are degrading organic pollution and enhancing stabilization of inorganic contaminants by hyperaccumulation and removal of substances when yielding out during the process. Target contaminants are hydrocarbons, pesticides, chlorinated substances, explosives and their components, heavy metals, radionuclides and excess nutrients. Plant species are selected regarding geographical objectives, evapotranspiration potential, growth rates, growth characteristics and bioaccumulation potential. For the extraction of metallic elements from soils the most common processes used are phytoextraction and phytostabilization (Chaudhry et al., 2008), but for organic contaminants - phytodegradation. Process of phytoextraction means accumulation of contaminants from the soil by plants hyperaccumulators (Wang et al., 2013), but phytostabilization is applied when contaminants in the soil and groundwater are immobilized by sorption on roots or precipitation within the root zone.

Metabolism can directly and indirectly destroy petroleum hydrocarbons by degrading them to other substances such as alcohols, acids, carbon dioxide and water (Eweis et al., 1998). The efficiency of phytoremediation depends on a choice of plant species and is able to accumulate metallic elements and metalloids such as selenium, copper, cadmium and zinc (Bañuelos et al., 1997; Ebbs et al., 1997; Brown et al., 1994).There are some species of trees and 


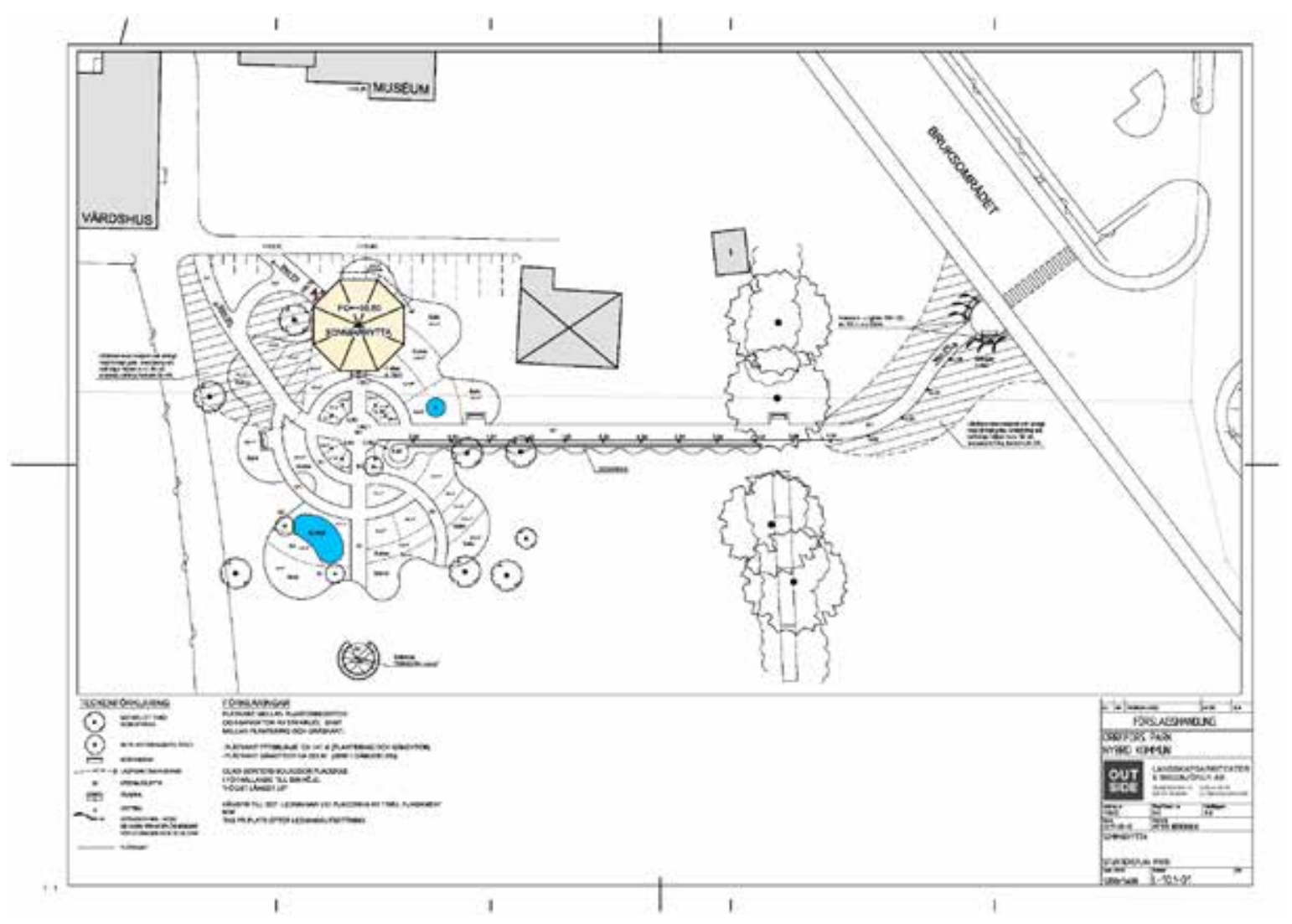

Figure 1. Project planning stage of the Orrefors Park. Pedestrian pathway planning, plant areas for phytostabilization purposes and recreation. This is a pilot area, a full-scale project includes additional territories.

shrubs whose roots are able to extend into the ground up to a depth of $18 \mathrm{~m}$ or deeper, e.g., Sarcobatus vermiculatus and Prosopis juliflora, but these species are not present in Europe (Landmeyer, 2012).

Species of willows (e.g., Salix viminialis) can be used for phytoremediation due to their deployed root system and ability to grow quickly (Blumberga, Kḷaviņš, \& Valtere, 2010). Five main processes dominate in phytoremediation: rhizofiltration, phytodegradation, phytostabilization, phytoextraction and phytovolatilization (Salt, Smith, \& Raskin, 1998).

The aim of research is to explore the phytoremediation approach for protection of environment and preventing the streaming of contaminant flows to hydrological systems. The main tasks of this research are: firstly, to evaluate effectiveness of short-term and/ or long-term phytoremediation projects; secondly, to evaluate effectiveness of contaminant reduction at the site; thirdly, to evaluate reduction of contaminant toxicity; fourthly, to evaluate cost effectiveness of phytoremediation.

\section{Materials and Methods}

\section{Case Study in Southern Sweden}

In our case study, Orrefors is a glasswork situated in a Swedish village in Småland. In 1914, with Johan
Ekman, the production of glass began. Nowadays there is only a glass factory that is situated in Kosta Boda. The Orrefors glass factory during performance created a lot of pollution in the surrounding area. Dumps emerged all around the village that affected the soil, the water and all the environmental quality (Etzkowitz, 2008; Hogland et al., 2014). The goal was to initiate a full-scale glass landfill excavation and design for a phytoremediation recreation glass parks and import gathered knowledge. Recreation parks after remediation will create a tourist area at the Orrefors glassworks, Sweden. Following excavation of the glass landfill site there, the project's partners intend to introduce plants capable of drawing heavy metals out of the soil (Hogland et al., 2014).

The Orrefors Park was designed and planned by collaborating environmental scientists and design professionals and is depicted in Fig. 1.

Unlike organic substances, heavy metals are essentially non-biodegradable and therefore accumulate in the environment. The accumulation of heavy metals in soils and waters poses a risk to the environmental and human health (Pilecka et al., 2017; Ali, Khan, \& Sajad, 2015).

Cleanup of heavy metal contaminated soils was utmost necessary in order to minimize their impact on 
the ecosystems. This is a challenging job with respect to cost and technical complexity.

For Orrefors Park project it was decided to apply phytoremediation technique, which is considered as a green alternative solution to the problem of heavy metal pollution.

Phytoremediation basically referred to the use of plants and associated soil microbes to reduce the concentrations or toxic effects of contaminants in the environments (Ali, Khan, \& Sajad, 2015).

By phytostabilization certain plants were used to reduce the mobility and bioavailability of pollutants in the environment. Plants can immobilize heavy metals in soils through sorption by roots, precipitation, complexation or metal valence reduction in rhizosphere. Phytostabilization limits the accumulation of heavy metals in biota and minimizes their leaching into underground waters (Ali, Khan, \& Sajad, 2015).

After phytoextraction each plant has to be removed from the site that leads to accumulation of huge quantities of hazardous biomass, which must be stored or disposed appropriately to minimize environmental risk. The methods of disposal of contaminated plants include approved secure landfills, surface impoundments, deep well injection or incineration (Padmavathiamma \& Li, 2007).

Since contamination of soils and waters by toxic heavy metals is a serious environmental problem, effective remediation methods are necessary. Physical and chemical methods for cleanup and restoration of heavy metal-contaminated soils have serious limitations like high cost, irreversible changes in soil properties, destruction of native soil microflora and creation of secondary pollution problems (Ali, Khan, \& Sajad, 2015; Padmavathiamma \& Li, 2007). In contrast, phytoremediation is a better solution to the problem (Blaylock \& Huang, 2000).
The effectiveness of phytoremediaton technology application to prevent the streaming of contaminant flows to hydrological systems were evaluated by using SWOT analysis with following criteria:

a) Short-term and/or long-term effectiveness;

b) Effectiveness of contaminant reduction at the site;

c) Reduction of contaminant toxicity;

d) Cost effectiveness of remediation.

\section{Results and Discussion}

Phytoremediation perspectives in Latvia

The main concern in Latvia is related to the costs and legislation, which often contradicts the business interests. Decision-makers from stakeholders should be strict about the process of preliminary studies as well as allow some flexibility in order to avoid too high costs and stagnation of the remediation process because of this reason (SUMATECS, 2008). Financial feasibility, market situation, environmental quality demands and recovery of the land resources are also among the important factors for decision-making. Phytoremediation techniques are recommended if the contamination level is low or average comparably to guidelines in most of legislator acts (Ellis \& Hadley, 2009; SUMATECS, 2008; Burlakovs \& Vircavs, 2012). The density of contaminated sites with mixt pollution in Latvia is presented in Figure 2. Until current time, no full scale phytoremediation applications have been performed in Latvia; however, several trials were done and some cases are described in this paper as follows.

According to Prokop et al. (2000) there was developed a conceptual decision scheme for remediation of contaminated sites with mixed contamination (see Figure 3).

The contamination with oil products can be stabilised by using five general approaches with

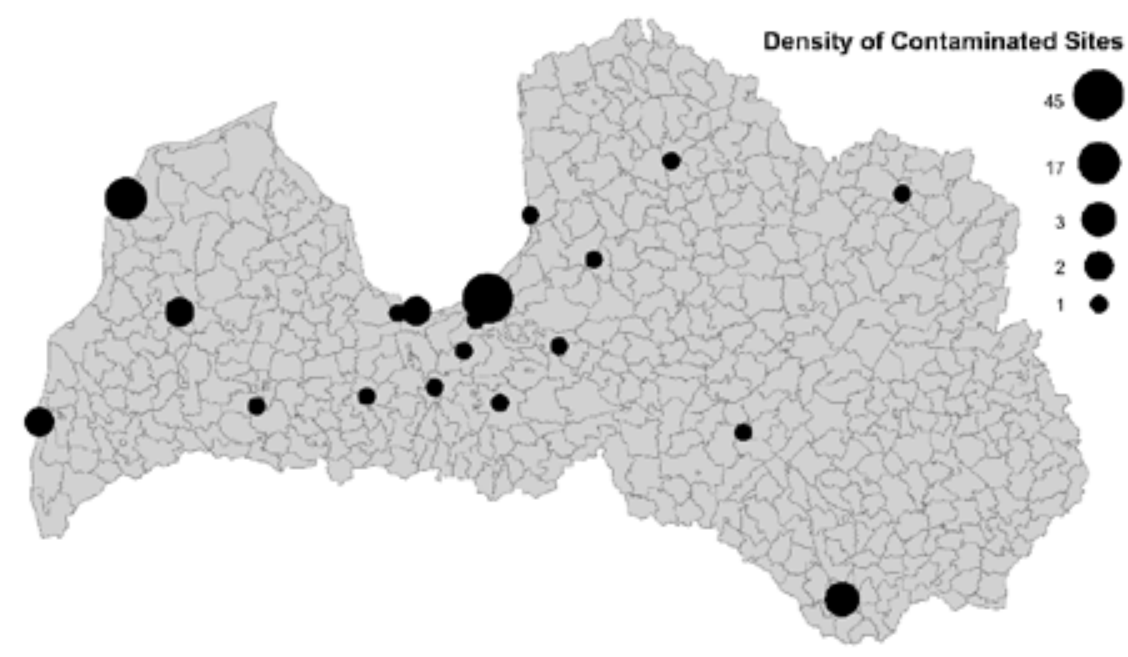

Figure 2. Geographical distribution and density of contaminated sites in Latvia residential areas. 


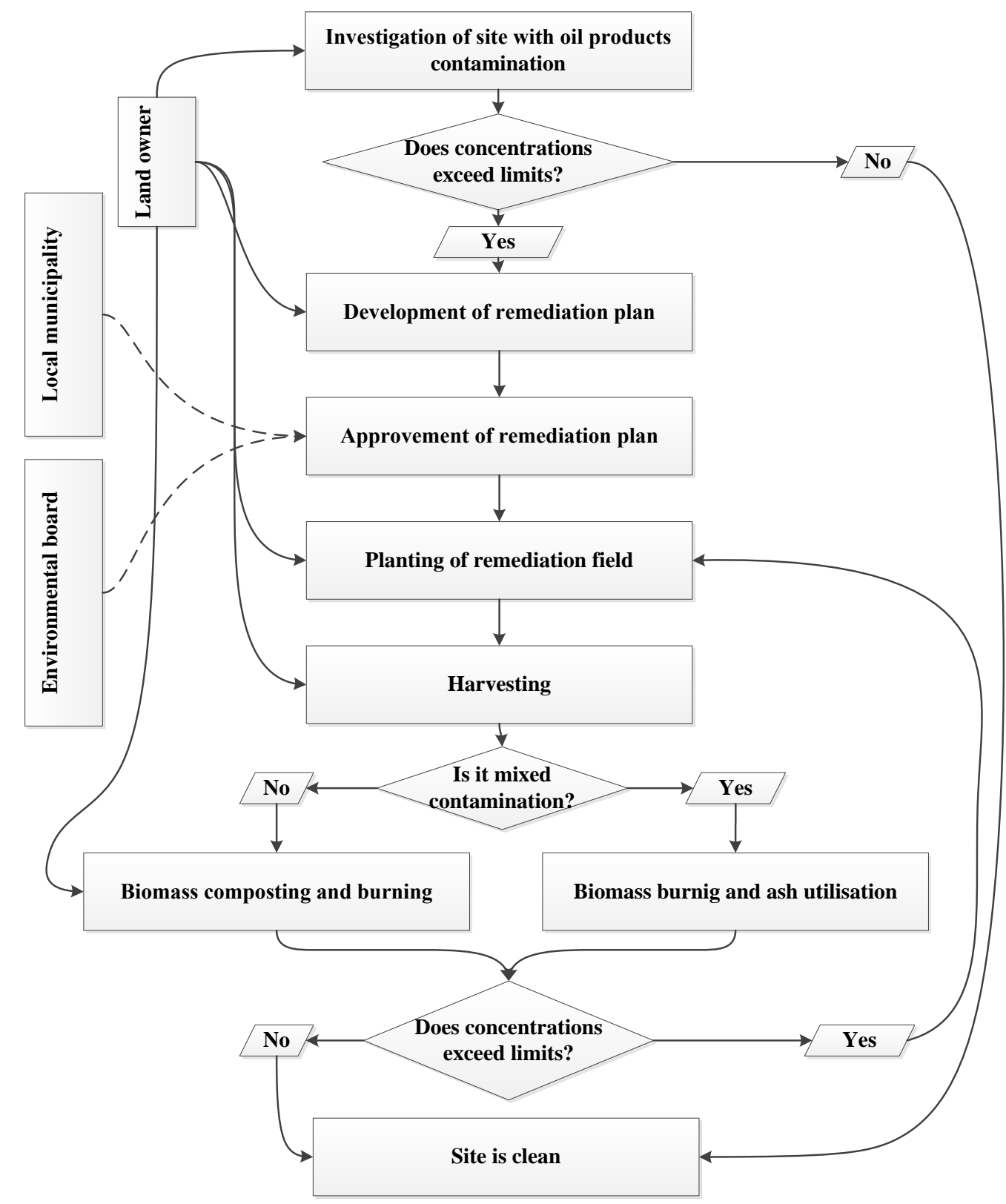

Figure 3. Decision scheme for remediation of contaminated sites.

plants, such as: alfalfa (Medicago Sativa L.), Willow (Salix spp.) and Poplar (Populus spp.). The aim of this approach is to stabilise contaminant in soil and reduce amount of contamination.

The process of phytoremediation project for protection of hydrological systems from oil products (hydrocarbons) can be performed in different ways (Ali et al., 2013).

If the pollution concentration of oil products is high or the contamination is at a depth that is not accessible to plants, planting can be formed in front of the contaminated area (see Figures 4 and 5) in order to reduce the groundwater flow towards pollution and prevent the extended leaching from the contaminated area (Ali et al., 2013).
If the concentration of oil products is low and no significant groundwater flow is observed in the contaminated area, then the contaminated area can be localized by using plantation.

In order to facilitate the purification of the area from pollution with oil products, vertical drainage wells with $50 \mathrm{~mm}$ in diameter can be installed and periodic watering of the plantation performed with drainage of polluted groundwater in the contaminated area should be done (see Figure 6) (Ali et al., 2013). Here engineers should plan that pollution stays on site and is not expanding aerially. In order to prevent contamination flow from neighbouring areas, the plantation should cover at least $10 \%$ wider area than the contaminated area. Watering will not only provide plants with water 


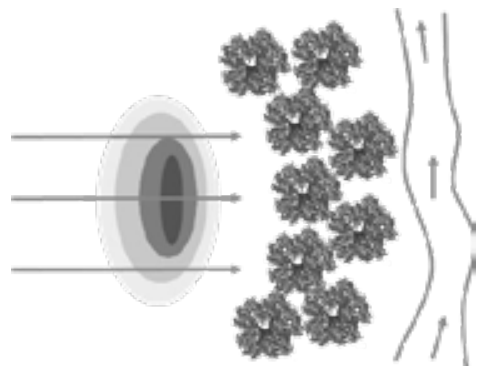

Figure 4. Landscape planning with planting for oil pollution prevention to hydrological systems.

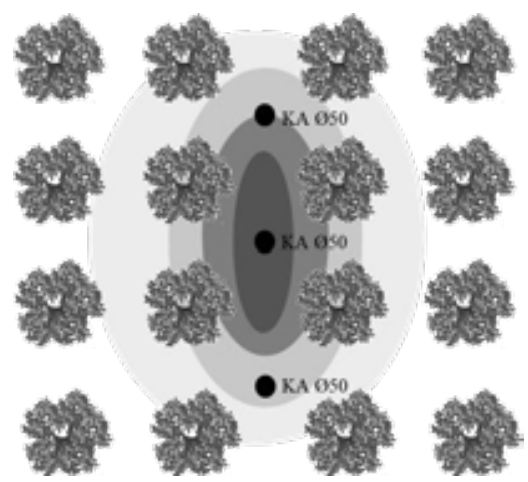

Figure 6. Landscape planning for planting in areas with uncertain groundwater flow direction combined with watering from vertical drainage wells (KAØ50).

but also increase the amount of oxygen in the soil, creating an appropriate microclimate for soil bacteria, thus accelerating purification of groundwater and soil from oil pollution contamination.

If the concentration of pollution is high and it is necessary to isolate the contaminated area, a tree plantation in the direction of the groundwater flow in front of the polluted area might be planned, moreovera ditch system in front of tree plantation can be settled. With that planned, it will prevent the surface water flow to the contaminated area (see Figure 7).

There are many possible solutions that might be combined and designed for each type of contamination, geography, climatic conditions and necessities defined by planners and decision-makers; therefore, it is important to plan remedial solutions by inviting in planning process engineers, decisionmakers, landscape architects, chemists and botanists.

\section{Conclusions}

The SWOT analysis of the effectiveness of phytoremediaton technology application to prevent the streaming of contaminant flows to hydrological systems for contaminated areas of low concentrations of mixed pollution shows: a) short-term and/or long-

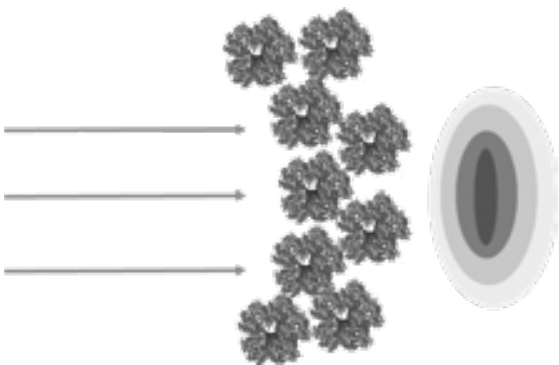

Figure 5. Landscape planning with planting for localizing contaminated area.

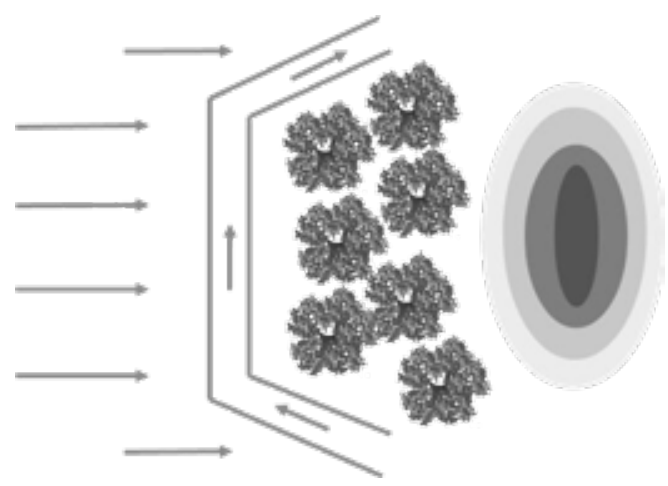

Figure 7. Planting scheme for isolation of contaminated site from hydrological influence.

term effectiveness of contaminant reduction on the site is set by concentration of pollution and the size of contaminated area; b) reduction of contaminant toxicity depends on the content of contamination and used technology in remediation process; c) cost effectiveness of remediation depends on the size of contaminated area and concentration of pollution. The landscape of today reflects the way the society has taken care of it. It needs an adequate landscape policy that establishes general principles, strategies and guidelines aimed at the protection, management and planning of landscapes. Moreover, when contamination is threatening environment including hydrological systems, the phytoremedial actions are the friendliest if applicable. Decision systems through cooperation are to be used for choosing the best available treatment of soil and water as well as prevention of contaminants mobility in water basins. Latvia is characterized with high density hydrological network and one of first aims of phytoremediation is to stabilize contamination to avoid leaching in groundwater and water streams. The most effective plants in Latvia climate conditions for phytostabilization are alfalfa (Medicago Sativa L.), willow (Salix spp.) and poplar (Populus spp.). Geographical density of pollution 
is concentrated in large cities and former military areas which may be transformed to greenfields through phyto-revitalization. The harvest utilisation of biomass depends on the type of pollution. The biomass from areas with oil products contamination can be composted or burned. However, the biomass from areas with mixed contamination (for example, oil products and heavy metals) has to be dried and transported to waste incineration. The PHYTECO project as an example from Southern Sweden was the immaculate pioneer example how forces may be joined to achieve the best available solution for treatment of contamination, thus, avoiding high costs and by adding the aesthetic and environmental value through the creation of Orrefors (Phyto)Park. Last but not the least aspect is education and environmental awareness that grows through generations,improving personal attitudes of many how to deal with the natural heritage to their children and grandchildren.

\section{Acknowledgements}

This study was supported by the Interreg Interactive Water Management (IWAMA) project and Swedish Institute sponsored PECEC initiative. Authors acknowledge Interreg South Baltic project "Reviving Baltic Resilience" on experience and knowledge exchange.

\section{References}

1. Ali, H., Khan, E., \& Sajad, M.A. (2013). Phytoremediation of heavy metals - Concepts and applications. Chemosphere. Volume 91, Issue 7, May 2013, pp. 869-881.

2. Bañuelos, G.S., Ajaw, H.A., Mackey, B., Wu, L., Cook, C., Akohoue, S., \& Zambruzuski, S. (1997). Evaluation of different plant species used for phytoremediation of high soil selenium. Journal of Environmental Quality. 26(3), 639-646.

3. Blaylock, M.J., \& Huang, J.W. (2000). Phytoextraction of metals. In: Raskin, I., Ensley, B.D. (eds.). Phytoremediation of toxic metals: using plants to clean-up the environment. New York, NY, John Wiley \& Sons, 53-70.

4. Blumberga, D., Kḷaviņš, M., \& Valtere, S. (2010). Vides piesārņojuma samazināšanas tehnolog̣ijas (Environmental pollution abatement technologies). No: Blumberga, D. (red.). Vides tehnologijas (Environmental Technologies). Rīga, Latvijas Universitāte, 117-184. (in Latvian).

5. Brown, S.L., Chaney, R.L., Angle, J.S., \& Baker, A.J.M. (1994). Phytoremediation potential of Thlaspi caerulescens and bladder campion for zinc and cadmium-contaminated soil. Journal of Environmental Quality. 23(6), 1151-1157.

6. Burlakovs, J., \& Vircavs, M. (2012). Heavy metal remediation technologies in Latvia: Possible applications and preliminary Case Study results. Ecological Chemistry and Engineering / Chemia $i$ Inžynieria Ekologiczna S, 19 (4), 533-547.

7. Chaudhry, T.M., Hayes, W.J., Khan, A.G., \& Khoo, C.S. (1998). Phytoremediation - focusing on accumulator plants that remediate metalcontaminated soils. - Australasian Journal of Ecotoxicology. 4, 37-51.

8. Directive 2008/1/EC of the European Parliament and of the Council of 15 January 2008 concerning integrated pollution prevention and control. Text with EEA relevance. Official Journal of the European Union, L 24/8.

9. Ebbs, S.D., Lasat, M.M., Brandy, D.J., Cornish, J., Gordon, R., \& Kochian, L.V. (1997). Heavy metals in the environment: Phytoextraction of cadmium and zinc from a contaminated soil. Journal of Environmental Quality. 26, 1424-1430.

10. Etzkowitz, H. (2010). The Triple Helix: University-Industry-Government Innovation In Action. London: Routledge, 2008. Translated into Russian.

11. Eweis, J.B., Ergas, S.J., Chang, D.P.Y., \& Schroeder, E.D. (1998). Bioremediation Principles. Boston, McGraw-Hill.

12. Hogland, M., Hogland, W., Jani, Y., Kaczala, F., Salomão, L., Luís, A., Kriipsalu, M., Orupõld, K., \& Burlokovs, J. (2014). Experiences of Three Landfill Mining Projects in the Baltic Sea Area - with focus on machinery for material recovery. Conf. proc., Linnaeus ECO-TECH'14, Kalmar, Sweden November 24-26.

13. Padmavathiamma, P.K., \& Li, L.Y. (2007). Phytoremediation Technology: Hyper-accumulation Metals in Plants. Water, Air, and Soil Pollution. Volume 184, Issue 1-4, September, pp. 105-126.

14. Pilecka, J., Grinfelde, I., Valujeva, K., Straupe, I., \& Purmalis, O. (2017). Heavy metal contamination and distribution in the urban environment of Jelgava. Research for Rural Development, Volume 1, pp. 173-179.

15. Prokop, G., Schamann, M., \& Edelgaard, I. (2000). Management of contaminated sites in Western Europe. Topic Report No 13/1999, Copenhagen: European Environment Agency, 1-171. 
16. Salt, D.E., Smith, R.D., \& Raskin I. (1998). Phytoremediation. Annual Review of Plant Physiology and Plant Molecular Biology. 49, 643-668.

17. Schrenk, V., Hiester, U., Kirchholtes, H.J., \& Bärlin, M. (2007). The Use of innovative remediation technologies in brownfield redevelopment projects. Proceedings 2nd International Conference on Managing Urban Land, EU, 10.

18. SUMATECS. (2008). Sustainable management of soil and groundwater under the pressure of soil pollution and soil contamination - Development of a decision tool system and its evaluation for practical application. Project No. SN-01/20. 2008.

19. Landmeyer, J.E. (2012). Introduction to phytoremediation of contaminated: historical foundation, hydrologic control, and contaminant remediation. Dordrecht, Springer Netherlands.

20. Wang, K., Huang, H., Zhu, Z., Li, T., He, Z., Yang, X., \& Alva, A. (2013) Phytoextraction of metals and rhizoremediation of PAHs in co-contaminated soil by co-planting of Sedum alfredii with ryegrass (Lolium perenne) or castor (Ricinus communis). International Journal of Phytoremediation, 15, 283-298.

21. 9VAC20-160-10. Definitions. (1997). Virginia Register. Volume 13, Issue 18, eff. June 26, 1997; amended, Virginia Register. Volume 18, Issue 18, eff. July 1, 2002. Retrieved March 9, 2018, from: http://leg1.state. va.us/cgi-bin/legp504.exe?000+reg+9VAC20-160-10. 